\title{
蠕動運動型混合搬送機による固体推進薬連続製造の検討
}

\author{
山田 泰之 ${ }^{* 1}$, 吉浜 舜 ${ }^{* 2}$, 岩崎 祥大 ${ }^{* 3}$, 芦垣 恭太 ${ }^{* 4}$, 松本 幸太郎 ${ }^{* 5}$, 羽生 宏人 ${ }^{* 6}$, 中村 太郎 ${ }^{* 1}$
}

\section{Study on peristaltic continuous mixing conveyor for composite propellant slurry mixing}

\author{
Yasuyuki YAMADA*1, Shun YOSHIHAMA ${ }^{* 2}$, Akihiro IWASAKI ${ }^{* 3}$, Kyota ASHIGAKI", \\ Kotaro MATUMOTO*5 ${ }^{*}$ Hiroto HABU ${ }^{* 6}$ and Taro NAKAMURA*1 \\ ${ }^{* 1}$ Faculty of Science and Engineering, Graduate school of Chuo University, 1-13-27 Kasuga, Bunkyo-ku, Tokyo 112-8551, Japan \\ ${ }^{* 2,{ }^{*} 4}$ Department of Precision Mechanics, Chuo University, 1-13-27 Kasuga, Bunkyo-ku, Tokyo 112-8551, Japan \\ ${ }^{* 3}$ Graduate University for Advanced Studies, Department of Space and Astronautical Science, School of Physical Science, SOKENDAI \\ 3-1-1 Yoshinodai, Chuo-ku, Sagamihara-shi, Kanagawa 252-5210, Japan \\ ${ }^{*},{ }^{*} 6$ Institute of Space and Astronautical Science,Japan Aerospace Exploration Agency (ISAS/JAXA) \\ 3-1-1 Yoshinodai, Chuo -ku, Sagamihara-shi, Kanagawa 252-5210, Japan
}

Received: 21 December 2016; Revised: 27 March 2017; Accepted: 8 May 2017

\begin{abstract}
In recent years, the demand for rocket launching has increased due to the development of space technology. However, using inexpensive rockets is not always possible. Although the cost of solid-propellant rockets is relatively reasonable, safely manufacturing a large amount of solid propellant is difficult, and the manufacturing process is disjointed. Therefore, safe and continues manufacturing of solid propellant is necessary. On the basis of the movements of the intestinal tract, we proposed that the movements required for transport and mixing of solid propellants are possible to achieve without the application of a large shear force. The peristaltic motion enables not only the mixing but also conveying even high viscosity slurry. By mimicking these intestinal movements, we have considered and developed the peristaltic pumping by driven artificial muscle as one of the candidates for the continuous and safety mixer. In this research, the mixing completeness of the composite solid propellant slurry by the peristaltic pumping mixer was estimated. The result showed that the mixer we proposed could mix the propellant slurry. In the propellant samples, these variances were sufficiently small. An appropriate combustion state as a solid propellant was confirmed.
\end{abstract}

Key words : Composite propellant, Continuous mixing, Peristaltic motion, Pneumatic actuator

\section{1. 緒言}

この近年, 社会インフラ等の高度化を目指し, 人工衛星等の宇宙利用の重要性が高まっている. そのため, 様々 なロケットの高性能・低コスト化が取り組まれている。固体然料ロケットは小型, 安価かつ取扱いが容易という 特徵があるが，現在の固体推進薬製造方法はバッチプロセスであり，設備・運用コストがロケット運用コストの 増加の主要因の 1 つとなっている。ささら，固体推進薬製造プロセスである推進薬スラリの捏和は，発火の危険 性のある高剪断力を用いた方法である。このため，推進薬製造の自動化，大量製造を困難としている.

本研究では, 固体推進薬スラリの製造プロセスの抜本的な変更により, 安全かつ連続的な捏和を実現し，設備・ 運用コストの大幅な低減を試みる。これらの要求を満たす低剪断力で安全性が高く連続的に高粘性流体を捏和可 能な装置として，腸管の蠕動運動に着目し，その動きを模擬した蠕動運動型混合搬送機を開発している(Suzuki and Nakamura, 2010). 蠕動運動を利用した運搬機は幾つか先行例が存在する. 1978年に, Spillmanはローラとゴムを利 用した蠕動運動搬送機を開発した (Spillman, 1978). 2005年に，Manganはウミウシの餌食行動を規範とした蠕動 運動グリッパを開発した(Mangan et al., 2005). しかし，これらは，小さい球状の固体は搬送できるが，液体は搬

\footnotetext{
No.16-00576 [DOI:10.1299/transjsme.16-00576], J-STAGE Advance Publication date: 22 May, 2017

*1 正員, 中央大学 理工学部（干112-8551 東京都文京区春日 1-13-27）

*2 学生員, 中央大学大学院 理工学研究科

*3 総合研究大学院大学物理科学研究科宇宙科学専攻（广252-5210 神奈川県相模原市中央区由野台 3-1-1）

*4 中央大学大学院 理工学研究科

*5 正員, 宇宙科学研究所 宇宙飛翔工学系（干252-5210 神奈川県相模原市中央区由野台 3-1-1）

*6 宇宙科学研究所 宇宙飛翔工学系

E-mail of corresponding author: yamada156@2009.jukuin.keio.ac.jp
} 
送できない. Miki は 人工的な食道を形状記憶合金で製作し，液体の搬送に成功している(Miki et al., 2010). しか し，この装置は食道程度の小さいサイズでは有効でも，固体燃料など工業的な製品を混合運搬するような装置と して大型化することは難しいと考えられる. 著者らはこれまでに軸方向繊維強化型人工筋肉(Nakamura, 2006)を用 いた独自の蠕動運動型混合搬送機（図1）を用いた高粘度スラリの捏和性能の優位性を検証し(Yoshihama et al., 2015), さらに, 固体推進薬模擬スラリを用いてポンプによる捏和システムの要素検討も進めてきた(Iwasaki et al., 2015). 本報告では，提案する混合搬送機によって，実際の固体推進薬の製造の実現可能性を示すことを目的と する．そこで，固体推進薬スラリの蠕動運動型ポンプでの捏和および特性取得を試みる．まず，固体推進薬模擬 材を用いて, ポンプの駆動圧力と捏和時間と捏和度の関係の傾向を把握する. そして, 得られた条件を用いて, 実際の固体推進薬を捏和して，その推進薬としての性能を燃焼速度試験で確認する。

本論文では，まず2章において, 製造を目指す固体推進薬の一般的な製造プロセスと先行例およびそれらの問題 点について説明する. 3章において, 本混合搬送機の規範としている蠕動運動およびそれを発生する腸管について 説明する.4章において, 腸管を模擬した蠕動運動型混合搬送機と，それを用いた推進薬製造プロセスについて説 明する．5章では，本混合搬送機を用いた模擬材実験を実施し，6章にて実推進薬での捏和実験検証を行う。最後 に，7章にて捏和した推進薬を，燃焼試験によって評価する.

\section{2. 固体推進薬製造プロセス}

固体推進薬はロケット燃料の一つであり，酸化剂，金属燃料，バインダ，可塑剂，硬化剂を混合し，これらを 練り固めて製造される.これらの組成, 酸化剂の種類, 粒子径, そしてバインダの種類と混合度合い, 例えば内 部の気泡分布によって燃焼速度が変化する. これらの特性と適切に管理し，ロケットの打ち上げに適合した推進 薬として製造・使用される．酸化剂としては過塩素酸アンモニウム(AP)が広く使用され，金属燃料はアルミニウ ム $(\mathrm{Al})$, 粉体粒子間を結合させるためのバインダには両端末水酸基を持つポリブタジエン(HTPB)が用いられる. 固体推進薬の既存の製造方法では, 図 2 に示すような金属製の容器内部に金属製の羽(棒)を回転させるプラネタ リミキサで原材料を混合している(Davenas, 2003)。この方法では高剪断力，擋拌羽根の故障などの事故による発 火の危険性があり, 一度に大量の推進薬を製造することは難しい. さらに, 捏和後に推進薬を容器からロケット へ自動で運搬する装置は無く，手動で搬送と注型が行われている。このように，固体推進薬製造プロセスは独立 したプロセス(バッチプロセス)である，そのため，固体推進薬製造には様々な安全管理や設備費，人件費等がか かり，ロケットの打ち上げ費用を高騰させ，結果として，打ち上げ頻度を低下につながっている．このような， 固体推進薬の連続的な製造による低コスト化については, 1980 年代にアメリカ(Cervenka, 1993)とフランス(Guery et al., 2005)で実現が試みられたが，基幹ロケットへの適用には至っていない. また，これら既存研究では推進薬 スラリが捏和・運搬される経路が金属製であるため, 静電気等での発火の恐れを排除できないなどの懸念がある. このように, 安全かつ連続的な固体推進薬の製造を可能とする混合機が望まれている.

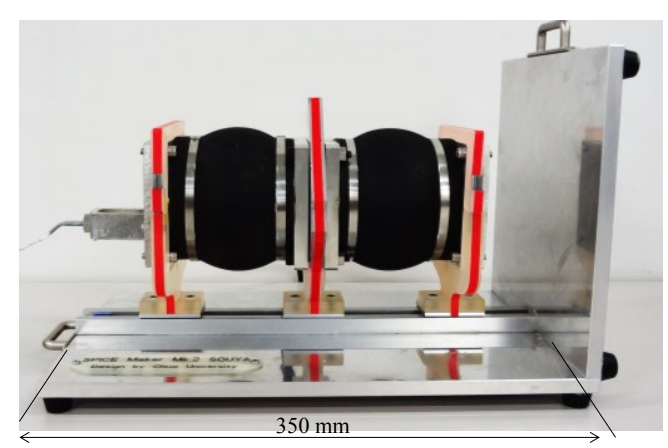

(a) 2 unit type peristaltic mixing conveyor.

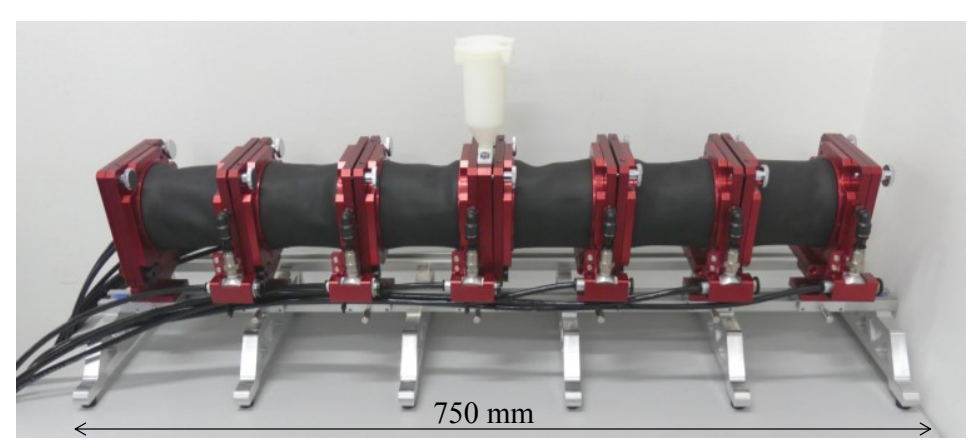

(b) 6 unit type peristaltic mixing conveyor.

Fig. 1 Peristaltic mixing conveyor. 


\section{3. 腸管の混合動作}

本研究では，固液混合の高粘度物質の連続的捏和方法として蠕動運動型混合搬送機の適用を検討している．本 章では，次章で紹介する本装置の規範とする蠕動運動について説明する.

腸管の構造を図 3 に示す．腸管には環状筋と縦走筋という 2 種類の筋層で構成されている. 腸管で環状に配置 されている筋肉を環状筋と呼び，径方向に収縮と弛緩を繰り返している. 腸管の軸方向に配置されている筋肉を 縦走筋と呼び，筋肉が収縮することで腸管が軸方向へ収縮する．このような動きを，蠕動運動と言い，腸管内で 食塊を搬送可能となる. 腸管の蠕動運動の概要を図 4 に示す. 腸管は食塊の接触により, 環状筋が収縮すること で食塊を押出す，収縮後は弛緩し，元の状態に戻る．この動作を連続的に組み合わせることで，食塊を搬送する 運動である蠕動運動を実現している．また，腸管には食塊を混合する働きがある．この混合動作には分節運動と 振子運動がある(三好，伊藤, 1985). 図 5(a)に分節運動，図 5 (b)に振子運動を示す．分節運動とは，一定の間隔を 空けて腸壁の環状筋が収縮と驰緩を繰り返し，腸管が多数の分節に分けたようになる運動である．この運動によ り，腸内部では食塊の分割と再結合が繰り返されて，混合される，一方，振子運動では縦走筋が収縮と驰緩を繰 り返すことで腸管が軸方向に伸縮し，食塊が腸管内で往復運動する．これにより，腸内部では食塊と消化液が混 合され，均一な食塊となる．以上のように腸管の径方向への収縮弛緩と軸方向への伸縮を行う運動を模擬する混 合搬送機を設計すれば，以下に説明する特性を得られると予想される.

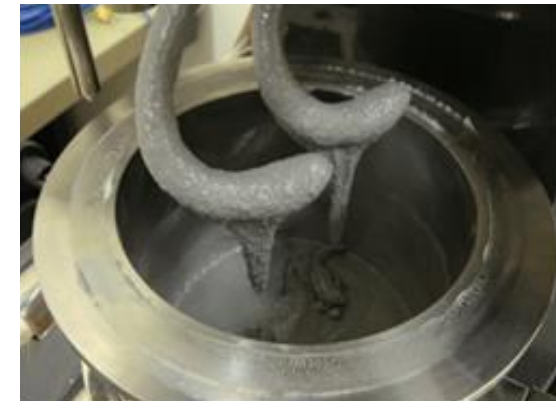

Fig. 2 Planetary Mixer.

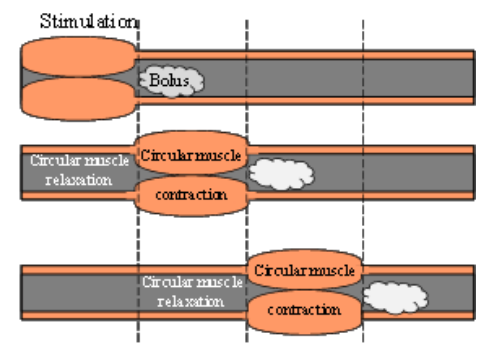

Fig. 4 Peristalsis movement.

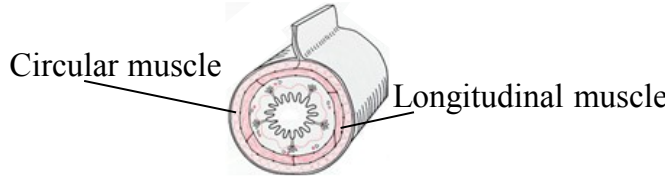

Fig.3 Structure of intestinal tract.

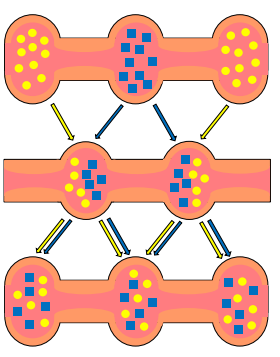

(a) Segmental movement.

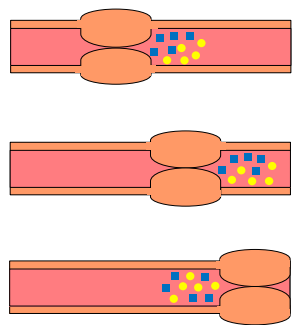

(b) Pendulum movement.

Fig.5 Mixing movement of intestinal tract.

\section{4. 蠕動運動型混合搬送機による固体推進薬製造}

\section{$4 \cdot 1$ 蠕動運動型混合搬送機}

蠕動運動型混合搬送機を用いた固体推蠕動運動型混合搬送機の外観を図 6(a)に, 諸元を表 1 に示寸. 図 6(a) の

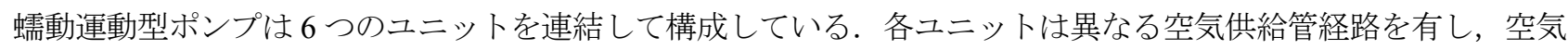
圧印加するユニットと時間を個別に制御できる．混合搬送対象が接触する管路内部は全て非金属であるゴム製で ある. 図 6(b)に蠕動運動型混合搬送機の 1 つのユニットの二面図を, 加圧時, 非加圧時で示した. 各ユニットは, 図 6(c)のように，外側に人工筋肉内側にゴムチューブを配した 2 重円筒構造となっており，この 2 つ間の空間 であるチャンバに加圧することで駆動する. 本混合搬送機は内部に液体等の混合・搬送対象がない場合に, $30 \mathrm{kPa}$ 印加時に内部管路が全閉する. また, この際本装置の外側に配置された人工筋肉が膨張し, 装置全長が伸縮され, 内部の物体を押し出寸効果を得られる. 1 つの混合搬送機で1度に装置の管路内容積の $88.7 \%$ にたる $2.2 \times 10^{-4} \mathrm{~m}^{3}$ の容積を排出できる. 


\section{4・2 蠕動運動型混合搬送機を用いた固体推進薬製造プロセス}

蠕動運動型混合搬送機を用いた固体推進薬製造プロセスを図 7 に示す. 固体推進薬の原材料の 1 つで高粘性流 体の HTPB(Hydroxyl Terminated Polybutadiene) と各種マイクロ粒子(AP 粒子や Al 粒子)を材料投入機から蠕動運動 型混合搬送機に投入して，環状の管路を循環させながら混合させる．管路は後述する調温装置を用いて温度調整 されている. 順次混合を行い, 所定の捏和度合であることをX 線画像により検査部で確認し, 分岐管路を用いて, 外部に排出して，ロケットへの注型を直接行なう。なお本図では，蠕動運動型混合搬送機が環状を形成している が，今後は環状や直列・並列配置，分岐合流等の接続形状と品質やシステム運用コスト等についても検討して， 最適なシステムを選定する予定である.

Table 1 Unit specifications.

\begin{tabular}{|c|c|}
\hline Diameter of conduit [mm] & 60 \\
\hline Maximum length [mm] & 540 \\
\hline Minimum length [mm] & 495 \\
\hline Weight [g] & 2660 \\
\hline
\end{tabular}

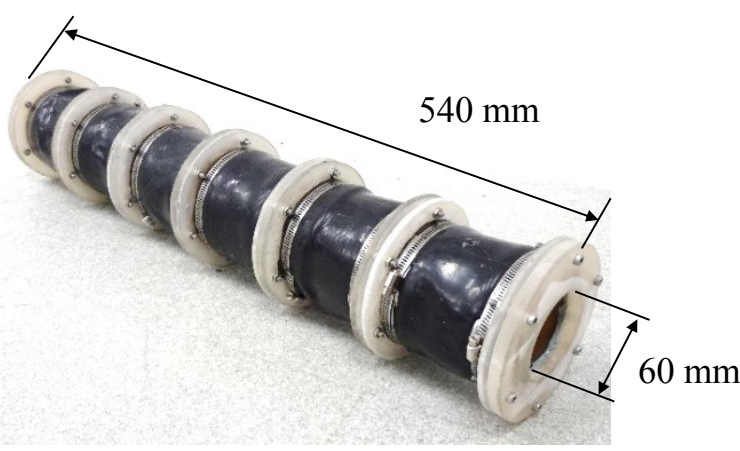

(a) Overview.

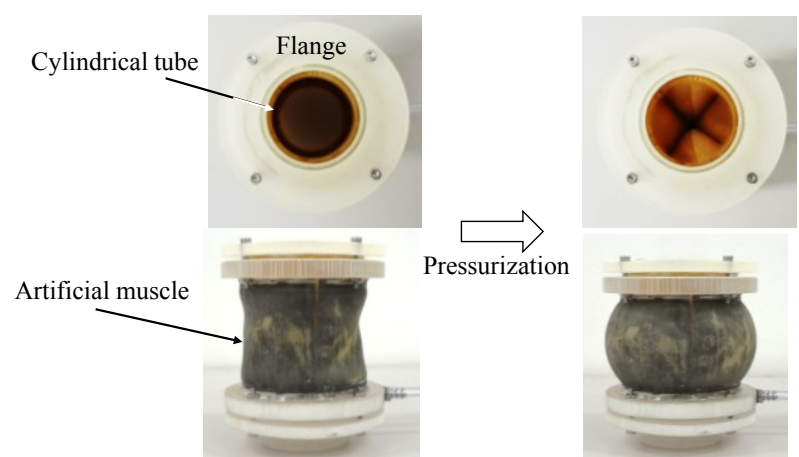

(b) Pressurization and unpressurization state of the unit.

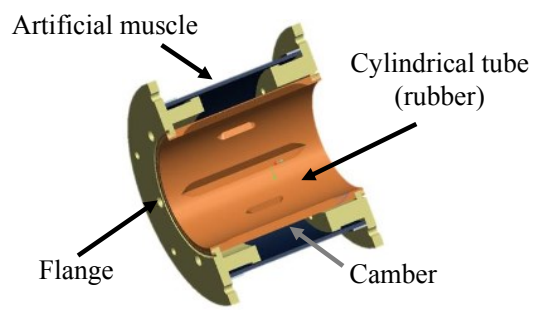

(c) Mechanism of unit.

Fig. 6 Peristaltic mixing conveyor and unit.

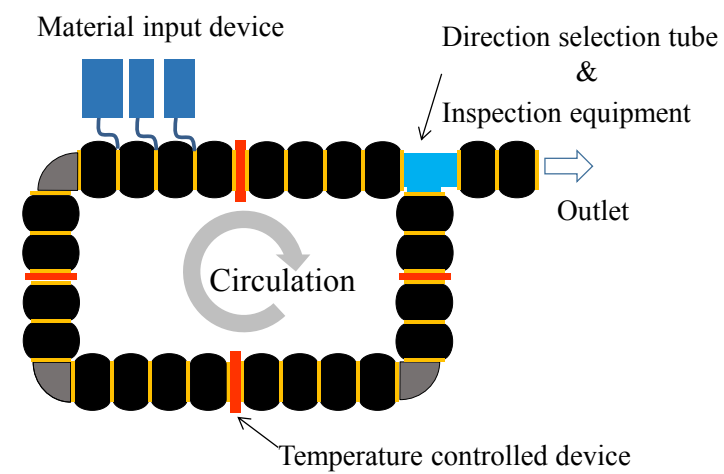

Fig. 7 Production process of solid propellant using peristaltic mixing conveyor. 


\section{5. 固体推進薬模擬材捏和試験}

\section{$5 \cdot 1$ 模擬材実験の目的}

固体推進薬製造時は，材料であるアルミ粉末や推進薬スラリなど爆発や発火の危険性のある物体を取り扱うた め，蠕動運動型混合搬送機での安全な捏和が確認できるまで，また適切な条件を定めるまでは，防爆性の高い試 験室で安全に特に留意して実験する必要があり，様々なパラメトリックな試験を円滑に行いにくい，そこで，推 進薬スラリの模擬材を用いた捏和試験を行い，どのような条件において，蠕動運動型混合搬送機で捏和が実現可 能であるかの傾向を事前につかみ，実際の固体推進薬での試験回数を軽減する.

\section{$5 \cdot 2$ 模擬材実験試験概要}

模擬材捏和実験では，模擬材を用いて推進薬スラリの捏和度とポンプへの印加圧力，捏和時間の関係の傾向を 実験的につかむ. 固体推進薬模擬材は，各種マイクロ粒子(AP 粒子や $\mathrm{Al}$ 粒子)の代わりに, 同粒子径のガラスビ 一ズを用いる，溶媒として，同粘度の高粘性流体を用いる．スラリの粘度計測には，応答性が良く，連続測定・ 流体測定が可能である回転振動式粘度計の VM-10A-H（セコニック製）を用いる．粘度計測は，装置内の捏和中 の模擬スラリを，中央部から 3 点，端部より 3 点の合計 6 点採取して実施する.

蠕動運動型混合搬送機の配置方法としては垂直配置と水平配置，運動としては分節運動と振子運動があり，それ らの組み合わせで 4 つのパターンが想定される。模擬材を用いた事前実験にて，水平配置かつ振子運動の場合が 最も捏和の効率が高かったため(Yoshihama et al., 2015)本実験においても，同様の方法をとる．実験では，図 1(a) に示すように振子運動が実現できる最小単位である 2 ユニットの蠕動運動型混合搬送機で振子運動を用いる。

これらで捏和した各条件での模擬材の粘度の分散を標準偏差として，これを捏和度(遠藤，井伊谷，1965)として 比較に利用する。捏和度が小さいほどより均一に捏和されていることになる。実験装置の概要を図 8 に示す.

模擬材は，混合搬送機側面にある蓋を開けて投入することが可能である．混合搬送機の駆動にはコンプレッサか らの圧縮空気を用いる，圧縮空気は，減圧弁(RJB500-LLC6-L，CKD)にて減圧後にマイコンを用いて ON/OFF 弁 を制御して供給する.混合搬送機一回の動作間隔は 0.1 秒から 0.1 秒ごとに任意に設定可能である.仮に 6 秒に設 定した場合，2 ユニットで実験すると，12 秒で模擬剤を振子運動で混合することとなる．各条件での実験では， 今回用いる模擬材を様々な運動条件で捏和し, 十分に捏和が確認できた条件(Yoshihama et al., 2015)を参考として 6 秒の押し出し時間で，36 分振子運動で捏和を基準とする。これは 180 回振子運動にあたる。なお，粒子と液体 の捏和において，捏和作動後に流動性を保つスラリを得られることが捏和の成功を示している. 捏和の条件が不 適切な場合は，捏和動作を継続しても，スラリに流動性が得られない。これは，プラネタリミキサ等の従来の混 合機では，スラリ内の粒子全体に液体物質が不均一に分布すると，その後均一にまとわり付けることが極めて難 しいためである。

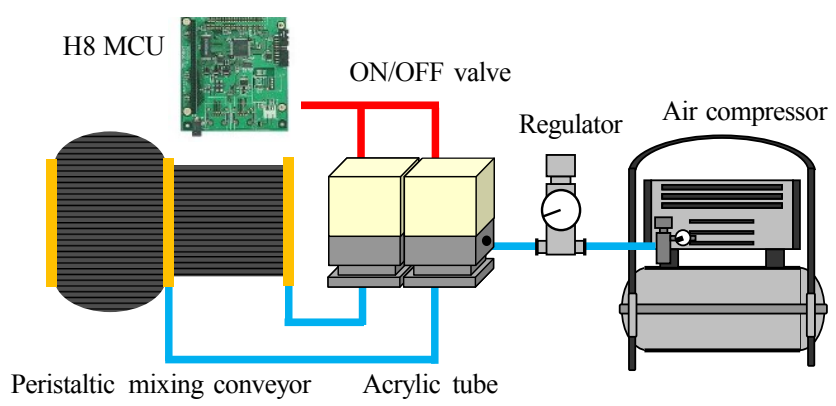

Fig. 82 unit type peristaltic mixing conveyor system.

\section{$5 \cdot 3$ 固体推進薬模擬材の選定}

本研究で使用する固体推進薬模擬材は，実際の固体推進薬捏和操作に適しているとされる粘度 $50 \mathrm{~Pa} \cdot \mathrm{s}$ 程度を 常温で模擬することを指標として選定した。これらは，固体推進薬スラリの粘度一温度相関(Iwasaki et al., 2015) を参考に，実際に捏和操作が行われる $58^{\circ} \mathrm{C}$ 以上での固体推進薬スラリ粘度から設定したものである。また，模 擬粒子は，実際の固体推進薬に利用される各種粒子と粒子サイズの分布が同等な粒子径と質量比率を設定する. 本実験では模擬粒子として工業用ガラスビーズ(粒子 $400 \mu \mathrm{m}: \mathrm{J}-36$ ，粒子 $200 \mu \mathrm{m}: \mathrm{J}-70$ ，粒子 $50 \mu \mathrm{m}: \mathrm{J}-320$ (ポッタ ーズ・バロディーニ社))を用いる. 高粘性流体としてはHTPB プレポリマである LBP2000 (CRAY VALLEY 社) 
を用いる. 実験では，全量が $350 \mathrm{~g}$ の模擬材を用いる．成分の質量比はHTPB：ガラスビーズ $=25: 75$ とする. ガ ラスビーズの各粒子径ごとの質量比は, M-V ロケットやイプシロンロケットの第一段エンジンの固体推進薬の物 性を参考に設定した. 具体的には, 質量比を $400 \mu \mathrm{m}: 200 \mu \mathrm{m}: 50 \mu \mathrm{m}=60: 15: 25$ とした. この模擬スラリ組成の材 料を HTPB に徐々に追加して，室温 $\left(25^{\circ} \mathrm{C}\right)$ にて，スパーテルを用いて手動で 1 時間捏和したところ，スラリの粘 度は $55.6 \mathrm{~Pa} \cdot \mathrm{s}$ を示し, 目標と近い数值となった. そのため, この模擬材は固体推進薬捏和操作時の推進薬スラ リの混合の特徵を模擬できると考える.

\section{$5 \cdot 4$ 捏和印加圧力と捏和度}

本実験では印加圧力を変数として, 印加圧力と捏和度合の関係の傾向把握のため, 模擬材で捏和実験する. 比 較する印加圧力は, $10 \mathrm{kPa}, 30 \mathrm{kPa}, 50 \mathrm{kPa}$ と 70kPa とする. なお, 本混合搬送機は $30 \mathrm{kPa}$ は内部に物体がない場合 に完全に閉塞し， $50 \mathrm{kPa}$ と $70 \mathrm{kPa}$ 印加時は内部に捏和後の模擬材がある場合でも内部管路が完全に閉塞する．一 方で, $10 \mathrm{kPa}$ 印加時は内部が空でも完全には閉塞しない条件である. 実験結果を図 9 示す. 印加圧力を高めるに

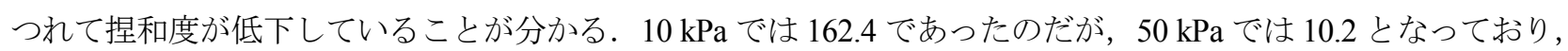
$70 \mathrm{kPa}$ でもあまり変化のない 13.4 となっている. そのため, 印加圧力と捏和度の関係は, 印加圧力を上げるとあ る一定值まで急激に捏和度が低下寸るが，その先はあまり変化しないことが確認できた。この傾向を 2 本の近似 直線で表し，その交点を図中に三角印で示した。この交点から，39kPaが，印加圧力と捏和度の関係が大きく変 わる圧力と予想できる．印加圧力が高いということは，その分システムが消費するエネルギが大きく，非効率的 である. 加えて, システム全体の強度を高めることや安全性の観点からも好ましくない，そのため，39 kPa を十 分に超えて, 捏和度が低下寸る $50 \mathrm{kPa} 70 \mathrm{kPa}$ 程度での捏和が捏和装置として蠕動運動型ポンプを利用する際に効 率的であると考える.

\section{$5 \cdot 5$ 捏和時間と捏和度}

固体推進薬模擬材の捏和度と蠕動運動型ポンプの捏和時間の関係性の傾向をつかむため，捏和試験を行う。ポ

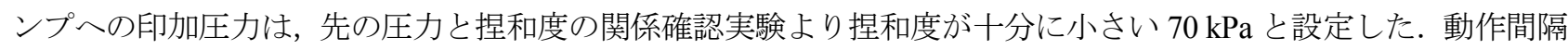
を 6 秒に設定し，各経過時間に内部の状態の可視的確認と，複数点試料の粘度を測定し，捏和度と捏和時間の関 係を把握する. 捏和時間は, 12 分 (60 回の振子運動), 24 分(120 回), 36 分 (180 回), 48 分(240 回)と 60 分(300 回)の 5 回実施した. 図 10 に実験結果として, 固体推進薬模擬材の捏和度と捏和時間の関係を示す. 図を見ると, 捏和時間が長くなるに従い，捏和度が低下していることが分かる。この傾向を 2 本の近似直線で表し，その交点 を図中に三角印で示した。 この交点から，36 分が，捏和時間と捏和度の関係が大きく変わる時間と予想できる.

捏和時間 36 分までは急激に捏和度が下がっており，36 分以降では捏和時間が長くなっても捏和度はあまり低 下しない事が分かる．捏和時間 12 分時のポンプ内部の様子は図 11(a)を見ると，管内の粒子の多くはバインダ (HTPB)と一体となっておらず，ほとんど捏和されていないことが分かる. バインダがまとわりついていない粉体 部分が残る模擬スラリ部分は粘度計による測定が不可能であったため, 乾燥した粉体領域外での測定を試みた. そのため実際の 捏和度はもっと大きいと考えられる. 一方，捏和時間 36 分では図 11(b)のように粒子とバイン ダが一体となっており, 全体的に均一に捏和されている様子が見られる. このように, 蠕動運動型混合搬送機に よって 36 分以上の捏和で, 固体推進薬の製造が期待できる.

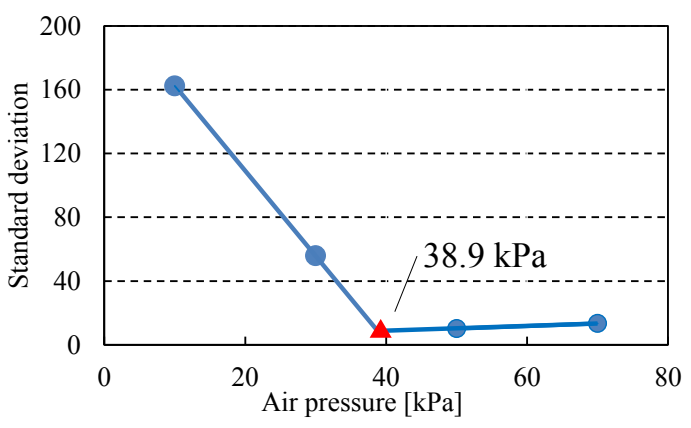

Fig. 9 Relationship between kneading degree and applied pressure of pump.

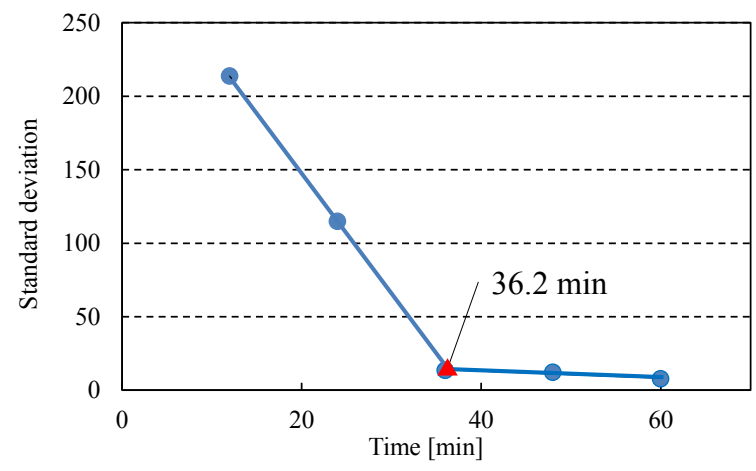

Fig. 10 Relationship between degree of kneading and kneading time. 


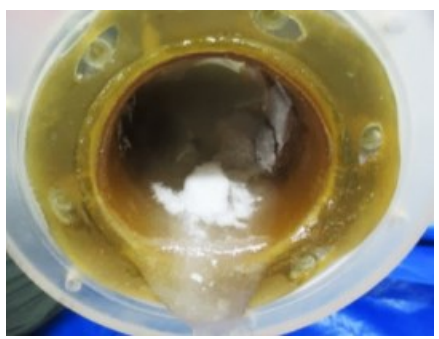

(a) In 12 minutes.

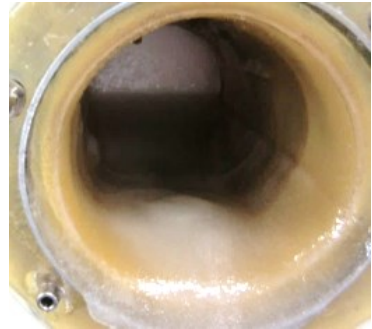

(b) In 36 minutes.

Fig. 11 Mixed state of simulated material.

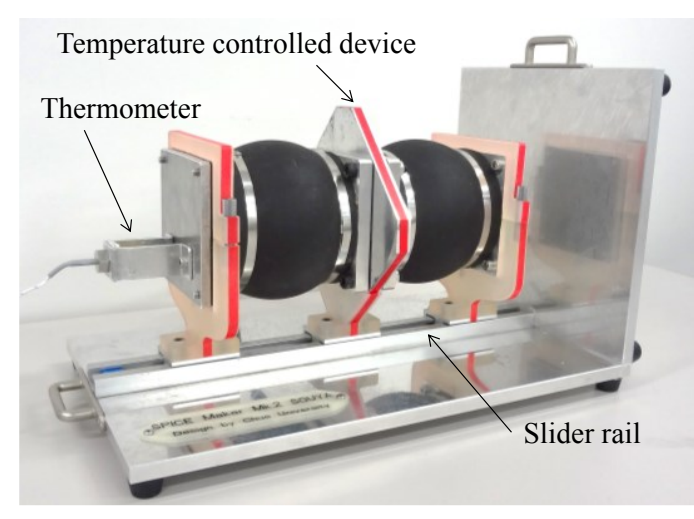

(a) Overview.

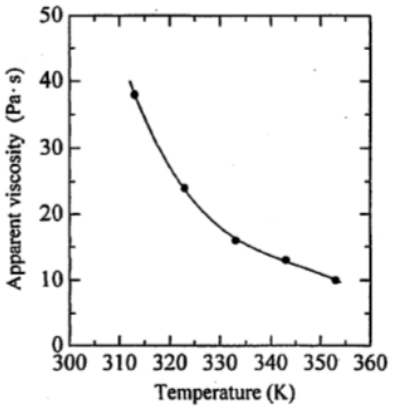

Fig.12 Relationship between apparent viscosity of HTPB prepolymer without IPDI and temperature (甲賀, 萩原, 1998).

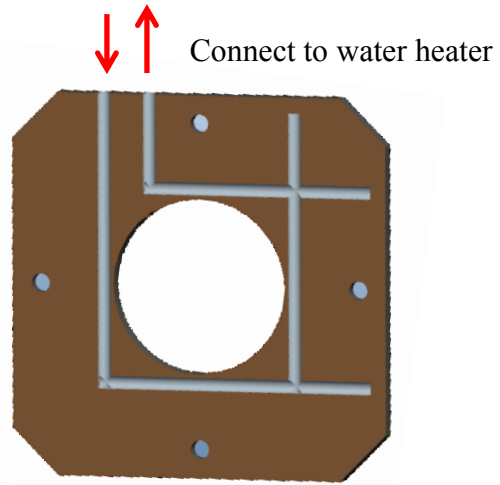

(b) Temperature controlled device.

Fig. 13 SPICE Maker Mk.II.

\section{$5 \cdot 6$ 圧縮捏和}

蠕動運動型混合搬送機の動作は，チャンバへの空気圧印加による外側人工筋肉の軸方向への収縮と，内側チュ 一ブの閉塞である.この動作により内部スラリが排除されて，捏和と搬送を実現している．本章での 2 ユニット 混合搬送機による捏和実験の結果において，捏和が印加圧力に依存性を持つことが分かった。 そのため，内側于 ユーブの閉塞によるスラリ圧縮によって捏和が進行していると予想できる.このような圧縮捏和では凝集してい る粒子塊一液体成分が毛細管現象によって内部に浸入し，捏和が進行する．捏和要素に他に剪断・摩擦・折り畳 みなどが挙げられるが，AP など高エネルギ物質を用いている固体推進薬に対しては圧縮捏和が安全で適してい ると考えられる.

\section{6. 蠕動運動型混合搬送機による固体推進薬捏和}

前章における，固体推進薬模擬材による各種試験によって，蠕動運動型混合搬送機を用いた固体推進薬捏和が 可能と期待される条件を選定した，本章では固体推進薬をその条件で，本混合搬送機で捏和して，その捏和途中 の目視確認と, 推進薬の燃焼試験によって, 本混合搬送機での燃料製造の可能性を確認する.

\section{$6 \cdot 1$ 捏和時の粘度調整のための加温装置}

固体推進薬の流動性を大きく左右する高粘度流体である HTPB は, 図 12 のように, 温度に依存した粘度変化 がある(甲賀, 萩原, 1998). 一方で, 固体推進薬スラリを取り扱う場合, その薬剂等々を含めて発火・爆発を防ぐ ために，室内温度を低温（18 ${ }^{\circ} \mathrm{C}$ 以下）と寸る場合が多い。この雰囲気では HTPB の粘度が高く，適切に捏和が現 実的ではない。 そのため, 従来の固体推進薬捏和時は, 調温装置を用いて, スラリを $58^{\circ} \mathrm{C}$ 以上（粘度 $50 \mathrm{~Pa} \cdot \mathrm{s}$ 以下）に加温して実施される．そこで，蠕動運動型混合運搬機を用いての固体推進薬捏和時も同様に，温度調整 が必要である. そこで, 調温装置備えた蠕動運動型混合運搬機として SPICE Maker Mk.II を開発した (図 13(a)). 本装置は模擬材試験時と同様に，2 ユニットの混合搬送機を水平に配置している. 混合搬送機のフランジ内部に は図 13(b)のように，管路が設けられており，熱交換を行える調温装置として働く。この調温装置に外部温水送水 機からの温水を通過させることで混合搬送機内部のスラリと熱交換する．混合搬送機には温度計を設置されてお り, 随時内部温度を監視できる. 


\section{$6 \cdot 2$ 実験条件}

実験装置の全体図を図 14 に示寸. ポンプへの印加圧力は, 捏和が十分に行えることを確認した印加圧力 $50 \mathrm{kPa}$ とした．さらに，推進薬試剤の粘度低下が大きく期待できる $58^{\circ} \mathrm{C}$ 付近まで温度を上昇可能とするため，調温装置 に $80{ }^{\circ} \mathrm{C}$ の温水を循環させる. 固体推進薬スラリは，酸化剂として粒子径が 400,200 と $50 \mu \mathrm{m}$ の過塩素酸アンモ ニウム $(\mathrm{AP})$ ，金属燃料として粒子径が $5 \mu \mathrm{m}$ のアルミニウム $(\mathrm{Al})$ ，バインダとして末端水酸基ポリブタジエン (HTPB) プレポリマ，可塑剤としてはアジピン酸ジオクチル $(\mathrm{DOA})$ を用いる. 固体推進薬スラリの構成割合は重 量比で AP : Al : HTPB : DOA= 68: 18: 12: 1 とする.さらに, AP 各粒子径の重量比は $400 \mu \mathrm{m}: 200 \mu \mathrm{m}: 50 \mu \mathrm{m}=41: 10$ : 17 とする．全量で $400 \mathrm{~g}$ となる．実験では，まず，HTPB，DOA，各 Al 粉を混合搬送機の片方の蓋を取り外し て，内部に一度に挿入して，15 分間予捏和を行った．その後に，同様の蓋から各種 AP を投入し，再度捏和操作 を再開した。また，AP 投入後に 10 分ごとに管内スラリを目視で観察した.

\section{$6 \cdot 3$ 固体推進薬の捏和度}

$\mathrm{AP}$ 粒子投入後の各時間の固体推進薬の捏和時の各時間での様子を図 15 に示寸．捏和開始より 30 分までは $\mathrm{AP}$ 粒子である白色粒子が目視で確認できる. また，この際の推進薬スラリ全体の流動性は殆ど確認されなかった. しかし，捏和時間 40 分以降では推進薬スラリに白色粒子が確認されず，一部の流動性が急増した. 50 分後には 推進薬の全体で流動性が増加しつづけ，90 分以降はスラリ状態であることが確認でき，捏和に成功したと判断し た.本結果より,蠕動運動型混合搬送機により固体推進薬スラリ捏和の過程は大きく 2 段階あること予想される. 第一段階は，スラリ自体は流動性を持たず蠕動運動型混合搬送機内の閉塞による内部材料の搬送で AP 粒子の濡 れ・粒子塊解砕が進行する段階である．第二段階は，AP 粒子の濡れが進行しバインダの液架橋力によってスラ

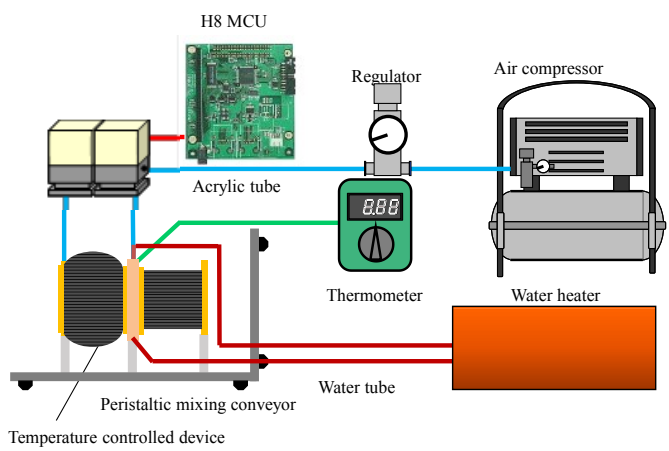

Fig. 142 unit type peristaltic mixing conveyor system with temperature controlled device.

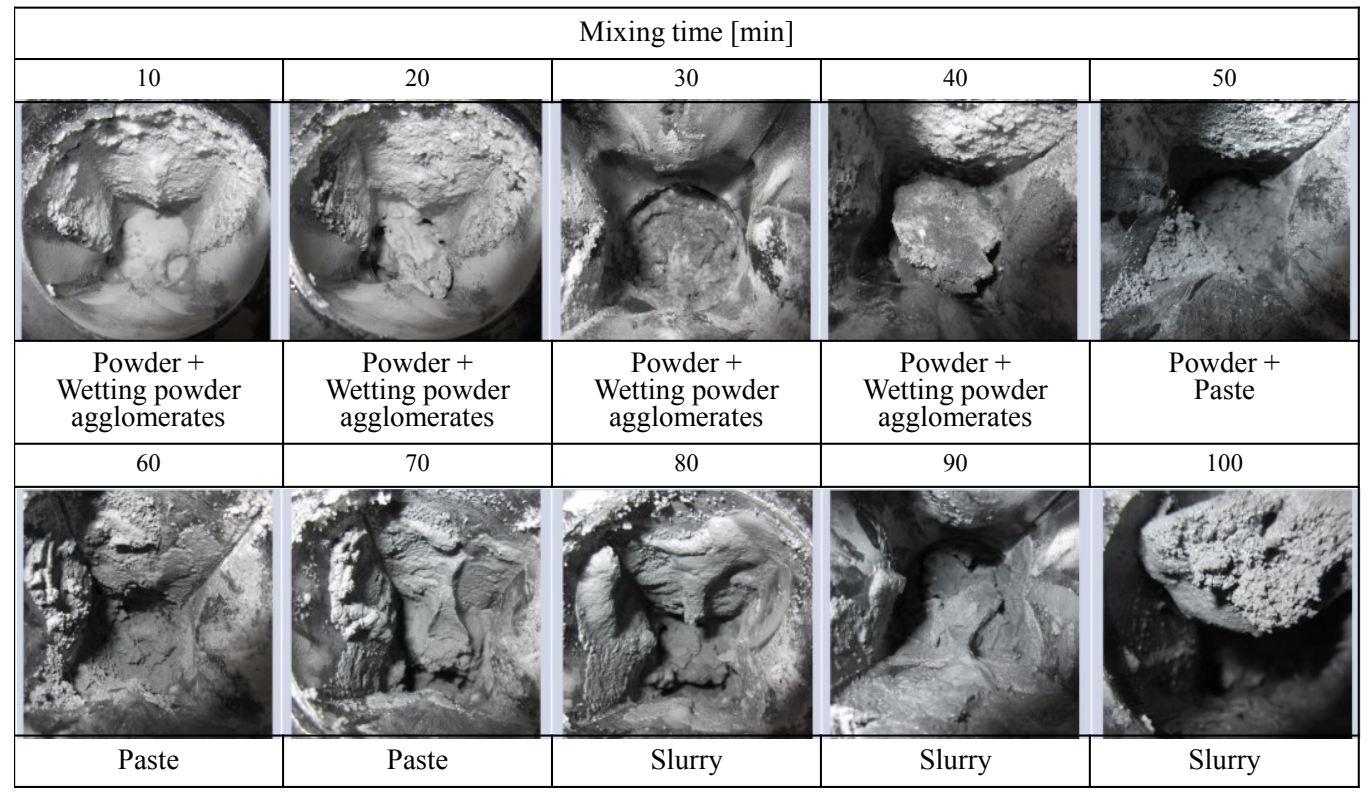

Fig. 15 States of solid propellant slurry. 
リに流動性が生じることで蠕動運動による圧縮・流動捏和が急激に進行寸る段階である．これは，プラネタリミ キサに代表される擋抖羽根の回転による剪断力を用いた従来の推進薬スラリ捏和装置とは大きく異なる．擋抖羽 根を用いる方法では，そもそもスラリに全体に流動性が無ければ捏和操作そのものが進まず停滞する．一方で, 蠕動運動型混合搬送機の場合，スラリに流動性が無くても混合搬送機の搬送能力と圧縮能力によって，高効率で の粒子塊解砕・捏和が進行している可能性が高い. 寸なわち, この蠕動運動型混合器の特色ある捏和メカニズム を応用すれば, 高効率な推進薬スラリ連続捏和システムを構築することができると期待できる.

\section{7. 固体推進薬燃焼試験}

固体推進薬としての性能を直接的に確認するために燃焼速度を消失ワイヤ式燃焼速度測定法で測定する. 実験 では，同材料物性の材料をプラネタリミキサで捏和した推進薬と比較実験を行う。これは，固体推進薬組成比が 十分に均一であり，推進薬の点火部が平面的に行われれば，推進薬がほぼ一方向に燃焼する特性を利用する．図 16(a)のように，長方形にカットした固体推進薬に数カ所に $0.3 \mathrm{~mm}$ のヒューズ線（半田線）を $10 \mathrm{~mm}$ 間隔で貫通 させ，燃焼で線が消失した際の電気抵抗の変化を記録することで燃焼速度を間接的に計測する．蠕動運動型混合 搬送機で捏和した推進薬スラリに硬化剤のイソホロンジイソシアネート (IPDI) を添加し, 真空中で脱泡処理を 行った後, $60^{\circ} \mathrm{C}$ の恒温槽内で硬化させた. 得られた推進薬を図 16(b)のチムニ型ストランドバーナで燃焼させた. 蠕動運動型混合搬送機で捏和した推進薬の燃焼時間と発生圧力の関係を図 17 に示す.横軸が燃焼室圧力 [MPa], 縦軸が燃焼速度 $[\mathrm{mm} / \mathrm{s}]$ であり，両対数プロットとなっている. 燃焼速度と圧力の関係はVieille の式により, 燃 焼速度 $r[\mathrm{~mm} / \mathrm{s}]$ は係数 $a$, 燃焼圧力 $p$ [MPa], 圧力指数 $n$ を用いて式(1)となる.

$$
r=a p^{n}
$$

そのため, 図 17 のグラフの近似曲線から圧力指数を求めることができる. 燃焼試験においては, 燃焼圧力を詳細 に一定值にすることは難しいため, 推進薬サンプルの比較は圧力指数を主に議論の対象とする.

プラネタリミキサで捏和した場合と比較して, 蠕動運動型混合器で捏和した推進薬の圧力指数はよく一致して おり, 同程度の燃焼特性であると言える. 蠕動運動型混合搬送機で実推進薬と同等の推進薬が得られるため, 本 混合搬送機を用いた連続捏和システムでも実用レベルが大きく期待できる.

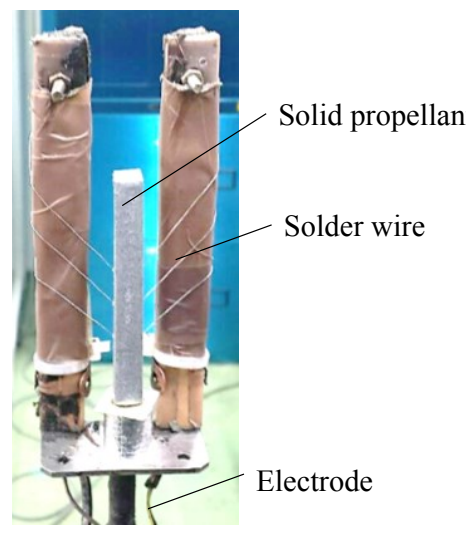

(a) Break wire method.

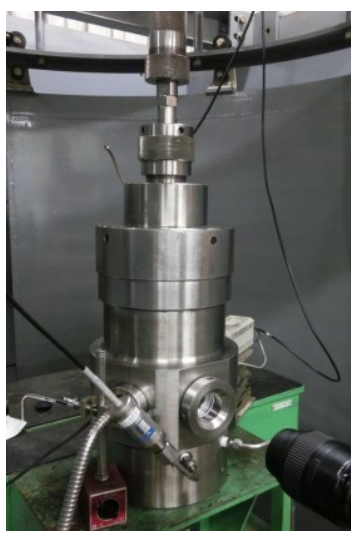

(b) Chimney type strand burner.

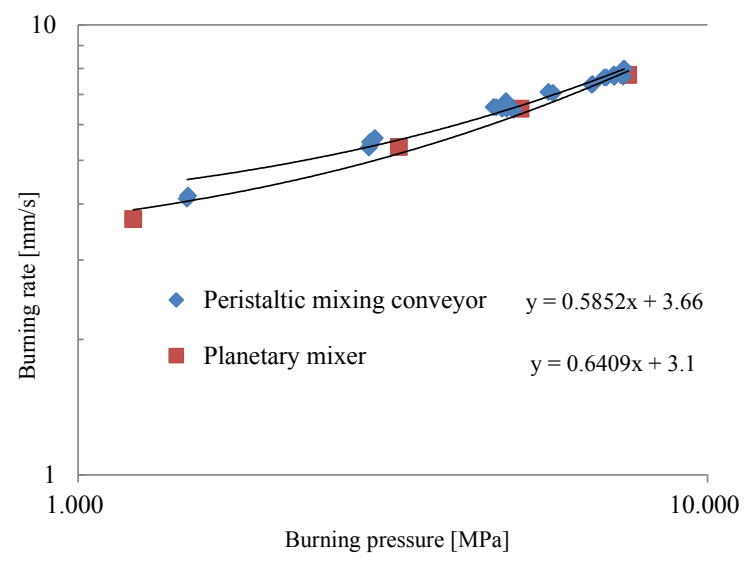

Fig. 17 Relationship between time of burning and generated pressure.

Fig. 16 Burn test. 


\section{8. 結 言}

本研究では, 固体推進薬の抜本的コスト低減に向けた安全かつ連続的な捏和システムを提案するため, 蠕動運動 型混合搬送機による連続捏和の実現可能性について検討した．得られた結果を示す．

・ 固体推進薬模擬材を用いた捏和実験により，39 kPa 以上の印加圧力で 36 分以上捏和を行うことで，推進ス ラリを適切に捏和可能であると予想した.

・ 蠕動運動型混合搬送機と加温装置を備えた固体推進薬捏和装置を開発した.

・ 蠕動運動型混合搬送機で固体推進薬スラリの捏和に成功した.

・蠕動運動型混合搬送機で捏和した推進薬が推進薬として十分な性能であることを燃焼試験により確認した.

以上のように，本混合搬送機を用いた連続捏和システムは実用レベルが大きく期待できる.

今後の展望として，本蠕動運動型混合搬送機を用いて，固体推進薬の連続捏和システムを構築する.

\section{文献}

Cervenka, A. C., The development of a continuous mix process for ASRM propellant production, AIAA paper, Vol.93, No. $2056(1993)$.

Davenas, A., Development of modern solid propellants, Journal of propulsion and power(2003), p.1115.

Elizabeth, V. M, Dan, A. K., Roger, D. Q., Greg, P. S., Joseph, M. M. and Hillel, J. C., A biologically inspired gripping device, Industrial Robot, Vol. 32, No. 1(2005), pp. 49-54.

遠藤一夫, 井伊谷鋼一(編集), 粉体工学ハンドブック, 粉体工学会(1965), pp.537-546.

Guery, J., Chounet, G., Gaudre, M., Tauzi, J. and Greco, P., A new continuous mixing facility for the demonstration of solid propulsion technologies of future ELV, 56th International Astronautical Congress (2005), pp.1-8.

Hirayama, Y., Suzuki, K. and Nakamura, T., Development of a peristaltic pump based on bowel peristalsis using for artificial rubber muscle, 2010 IEEE/RSJ international conference on intelligent robots and systems, WeCT3.4 (2010), pp. 3085-3090.

Iwasaki ,A., Matsumoto, K., Ban, K., Yoshihama, S., Habu, H. and Nakamura ,T., The Continuous mixing process of composite solid propellant slurry by the artificial muscle actuator, The ISTS special issue of transactions of JSASS aerospace technology japan, The japan society for aeronautical and space sciences(2015), p. 5-a-03.

甲賀 誠, 萩原 豊, 過塩素酸アンモニウム/末端水酸基ポリブタジエン系推進薬の製造性に関する実験的研究未硬化推進薬の粘度に及ぼす操作温度の影響-, 火薬学会誌, Vol.59 No 1(1998).

Miki, H., Okuyama, T., Kodaira, S., Luo, Y., Takagi, T., Yambe, T. and Sato, T., Artificial esophagus with peristaltic motion using shape memory alloy, in International journal of applied electromagnetics and mechanics, Vol. 33 (2010), pp. 705- 711 .

三好秋馬，伊藤漸，消化管運動機能調節剤〜基礎と臨床〜，医薬ジャーナル社 (1985)，pp. 193-212.

Nakamura, T., Experimental comparisons between McKibben type artificial muscles and straight fibers type artificial muscles, in Proc. SPIE Int. Confarence of Smart Structures, Devices and Systems III (2006), p. 641424.

Spillman, J., Peristaltic conveyors, The chartered mechanical engineer : CME ; the journal of the Institution of mechanical engineer, Vol. 25, No. 5 (1978), pp. 55-57.

Yoshihama, S., Ban, R., Nakamura, T., Iwasaki, A. and Habu, H., Mixing of solid propellant by peristaltic pump based on bowel peristalsis, Proceedings of IEEE international conference on intelligent robots and systems, Hamburg, Germany, (IROS2015)(2015), pp. 3862-3868. 


\section{References}

Cervenka, A. C., The development of a continuous mix process for ASRM propellant production, AIAA paper, Vol.93, No. 2056 (1993).

Davenas, A., Development of modern solid propellants, Journal of propulsion and power(2003), p.1115.

Elizabeth, V. M, Dan, A. K., Roger, D. Q., Greg, P. S., Joseph, M. M. and Hillel, J. C., A biologically inspired gripping device, Industrial Robot, Vol. 32, No. 1(2005), pp. 49-54.

Endo, K. and Iitani, K. ed., Powder engineering handbook, The society of powder technology(1965), pp.537-546(in Japanese).

Guery, J., Chounet, G., Gaudre, M., Tauzi, J. and Greco, P., A new continuous mixing facility for the demonstration of solid propulsion technologies of future ELV, 56th International Astronautical Congress (2005), pp.1-8.

Hirayama, Y., Suzuki, K. and Nakamura, T., Development of a peristaltic pump based on bowel peristalsis using for artificial rubber muscle, 2010 IEEE/RSJ international conference on intelligent robots and systems, WeCT3.4 (2010), pp. 3085-3090.

Iwasaki ,A., Matsumoto, K., Ban, K., Yoshihama, S., Habu, H. and Nakamura ,T., The Continuous mixing process of composite solid propellant slurry by the artificial muscle actuator, The ISTS special issue of transactions of JSASS aerospace technology japan, The japan society for aeronautical and space sciences(2015), p. 5-a-03.

Kohga, M. and Hagihara, Y., Experimental study on processability of ammonium perchlorate hydroxyl terminated polybutadiene composite propellant, KAYAKU gakkaishi Vol.59, No 1 (1998) (in Japanese).

Miki, H., Okuyama, T., Kodaira, S., Luo, Y., Takagi, T., Yambe, T. and Sato, T., Artificial esophagus with peristaltic motion using shape memory alloy, in International journal of applied electromagnetics and mechanics, Vol. 33(2010), pp. 705- 711(in Japanese).

Miyoshi, S. and Ito, S., Digestive tract contraction exercise detailed exposition, Gastrointestinal motility modifiers - basic and clinical -, Osaka: Medicine and Drug Journal (1985), pp.193-212(in Japanese).

Nakamura, T., Experimental comparisons between McKibben type artificial muscles and straight fibers type artificial muscles, in Proc. SPIE Int. Confarence of Smart Structures, Devices and Systems III (2006), p. 641424.

Spillman, J., Peristaltic conveyors, The chartered mechanical engineer : CME ; the journal of the Institution of mechanical engineer, Vol. 25, No. 5 (1978), pp. 55-57.

Yoshihama, S., Ban, R., Nakamura, T., Iwasaki, A. and Habu, H., Mixing of solid propellant by peristaltic pump based on bowel peristalsis, Proceedings of IEEE international conference on intelligent robots and systems, Hamburg, Germany, (IROS2015)(2015), pp. 3862-3868. 